\title{
INFORMATION ABOUT THE HOST COUNTRY BEFORE IMMIGRATION: HOW IS IT RELATED TO IMMIGRANTS' BASIC SOCIODEMOGRAPHIC CHARACTERISTICS?
}

\author{
Aleksandra Batuchina ${ }^{1}$, Regina Saveljeva ${ }^{2}$, Gunta Viksne ${ }^{3}$, Zornitsa Staneva ${ }^{4}$ \\ Klaipėda University (Lithuania)
}

\begin{abstract}
The study has been conducted within the ERASMUS+ KA2 partnership project "Improving the initial education of adult immigrants". Research is based on the anonymous survey in which took part 1127 legal adult immigrants from outside the European Union. The study was performed in 2017 in the six European Union countries: Lithuania, Latvia, Romania, Bulgaria, Italy and Belgium. The purpose of this article is to investigate how information about the host country before immigration is related to immigrants' basic sociodemographic characteristics, i.e.: age, gender and education. Statistical data analysis showed a statistically significant difference between the information, which immigrants knew before their arrival in the host country, and education as well as age groups. However, there were no statistically significant differences found between the information, which immigrants knew before their arrival in the host country, and immigrants' gender. Moreover, information that immigrants lack most prior to their arrival is related with health care and the employment system as well as the ability to learn the hosting country's official language.

KEYWORDS: migration, information practices, sociodemographic characteristics.
\end{abstract}

JEL CODES: J15, D83.

DOI:

\section{Introduction}

Migration as a social phenomenon has been well known since the ancient times. People have been migrating in all times primarily in search of better living conditions and/or sources of income. However, in recent years, it has become particularly acute in the case of military conflict in the Middle East countries, also due to labour shortage and the need for labour migration (Determining labour shortages and the need for labour migration from third countries in the EU, 2015). Thus, a huge wave of immigrants surged the European Union - only during 2015 arrived more than a million people (BBC News, 2016). According to data of 2017, the EU countries accounted one-third of the population as immigrants (Population Reference Bureau, 2018; World Bank, 2018). No doubts, within the countries of the EU, migrants from outside the EU (so-called

1 Aleksandra Batuchina - PhD, lecturer at the Department of Public Administration and Social Geography, Klaipėda University, Lithuania

Scientific interests: migration, phenomenology

E-mail: aleksandra.ro@gmail.com

2 Regina Saveljeva - PhD, lecturer at the Department of Education, Klaipeda University, Lithuania

Scientific interests: research methodology, quantitative research methods

E-mail: reginasaveljeva@gmail.com

3 Gunta Viksne - expert in migration, NGO "Shelter 'Safe House”, Riga, Latvia

Scientific interests: migration, refugees, asylum seekers

E-mail: ici.riga@integration.lv

4 Zornitsa Staneve - Chair of board of NGO "Foundation for development of the cultural and business potential of civil society", Sofia, Bulgaria

Scientific interests: innovative social services, service delivery and new methods of informal support and care

E-mail: zornitsastaneva@gmail.com 
third-country nationals) face particular challenges together with the highest rates of unemployment and the greatest rates of job loss associated with the global economic crisis (Rechel, Mladovsky et al., 2013). As a result, migration has become a huge challenge for immigrants themselves and their host countries. In 2011, the European Commission even adopted the position on European integration of the third country nationals, seeking to increase the economic, social and cultural benefits of migration in the European Union. The goal announced is that integration of immigrants has to be successful in the European Union; new full-fledged members of the community should actively participate in economic, social, cultural and political life of their host cities and regions (Action Plan on the integration of third country nationals, 2016). Nevertheless, it is worth noticing that the more successful immigrants are in the labour market, the higher will be their net economic and fiscal contribution to the host economy (Algan, Dustmann, Glitz, Manning, 2010).

One of the comforting facts of successful integration is primary information about the host country. As a result, naturally modern technology and communication tools make the inevitable impact on the migration process (Castells, 2009). In this way, communication tools help a new expatriate migrant to avoid isolation, allows to get to know a new country and its culture, delivers learning opportunities (language, profession), allows to better understand/feel the country's public language and identity (Redecker, Hache, Centeno, 2010). Also, according to B. Dekker and M. Siegel (2013), communication is a medium for research analysing the role of communication tools in helping immigrants to integrate in a new country.

Immigrants' needs for information vary. According to N. Caidi, D. Allard and D. Dechief (2008), the top information needs for longer established immigrants include: health information; employment information; educational information; political information and current events (especially news about the country of origin); language learning information; information about transportation; information about identity construction. As a result, a migrant occurs in the environment, information about which he does not have at all. B. Mehra and D. Papajohn (2007) call it a "culturally alien information environment".

Without information immigrants are not able to integrate into the host society. Consequently, lack of information creates conditions and barriers that prohibit full participation in education, work, and every-day life (Lloyd, Kennan, Thompson, Qayyum, 2013). However, research shows that most recently immigrants arrive in their host country without any knowledge of the country's language, not knowing the country's social life and cultural features of life values, norms and traditions (Algan, Dustmann, Glitz, Manning, 2010). Therefore, those without access to information run the risk of becoming increasingly excluded from the mainstream information sources and may fail to develop the capacity to fully settle, recognize and take up opportunities, as well as participate in society as full citizens. As a result, N. Caidi and D. Allard (2005) states that without mechanisms in place to ensure that newcomers are adequately integrated in their newly adopted society, these groups may be at greater risk of being pushed to the margins of the democratic process or may feel isolated and lacking opportunities and choice.

In addition, information sources can be very different. Literature on immigrants and information show that major sources how immigrants get information about the host country are as follows: the Internet and digital technologies (Andrade, Doolin, 2016), government and settlement agencies; newspapers, radio, TV. Also, it is known that immigrants are a common source of information for each other, providing one another with "traditional" settlement information as well as leisure information, cultural information, and support (Caidi, Allard, Dechief, 2008).

It is increasingly clear from the literature that implications of social exclusion hurt not only those who are excluded (their needs are not met), but also the broader society and the economy (Caidi, Allard, 2005). Moreover, poor economic success may lead to social and economic exclusion of immigrants and their descendants, which in turn may lead to social unrest, with riots and terrorism as extreme manifestations (Algan, Dustmann, Glitz, Manning, 2010). So, seeking and gathering information is a critical part of the immigration process (Shoham, Strauss, 2007).

The problem of research. Despite the information sources, even the amount of it and issues which might occur if there is no such information, there are always barriers and challenges which decrease or increase the access to this information, namely: language; cultural differences; isolation and small networks; 
and no access to local news sources (Caidi, Allard, Dechief, 2008). Moreover, as N. Caidi, D. Allard and D. Dechief (2008) state, demographical characteristics are also important as factors influencing acceptance of information, i.e., age, gender differences and education are among others that play an important role too. For instance, scholarly findings on the link between age and information acceptance during migration show that younger immigrants and students have overlapping but also significantly different information needs and sources than working or older immigrants (Caidi, Allard, Dechief, 2008). Therefore, younger immigrants have greater access and amount of information about the host country. Moreover, some considerations suggest that assimilation profiles of women from less traditional source countries will be steeper than men's (Blau, Kahn, Papps, 2011). Moreover, it might sound logical that immigrants with higher education level have better access to information about the host country, however there is not enough research on this topic, while, for instance, N. Caidi, D. Allard and D. Dechief (2008) emphasize that even students (who are generally considered to be better educated and economically better off) face language barriers as a result of lack of information.

Even though it is clear that these demographic factors might prevent or encourage migrants' successful and dignified integration in the host country as well as promote social exclusion, alienation of people and other social issues and values, these three demographic characteristics and their interrelation with information about the host country have been poorly investigated in scientific literature. Therefore, the purpose of the article is to investigate how information about the host country before immigration and afterwards is related to the immigrants' basic sociodemographic characteristics: age, gender and education.

The tasks of research: (1) To investigate how information about the hosting country before immigration is related to the immigrants' basic sociodemographic characteristics: age, gender and education; (2) To investigate how the information, which immigrants lacked on their arrival in the host country, is represented within the immigrants' basic sociodemographic characteristics: age, gender and education.

The object of the research: the information about the hosting country before immigration.

Research methods. Data collection method using written survey; data analysis methods: non-parametric and descriptive statistical analyses.

\section{Methodology and data analysis}

The current article presents and analyses the part of data received from a survey, which was obtained during the study on immigrants conducted in 2017 in six project partner countries. The study was carried within the ERASMUS+ project "Improving the initial education of adult immigrants", No. 2016-1-LT01KA204-023223. The aim of the project was to create and test innovative educational tools for immigrants based on digital technology that would help them to acquire basic knowledge and understanding about the host country's sociocultural life. Whereas the main aim of the survey was to investigate what are the specific social and educational needs of immigrants living in the mentioned countries.

The survey was conducted in Lithuania, Latvia, Romania, Bulgaria, Italy and Belgium by researchers from 9 partner organizations participating in the project. The performed surveys have distributed as follows: $19.0 \%$ of the surveys were conducted in Belgium, $18.2 \%$ in Romania; $18.6 \%$ in Bulgaria; $17 \%$ were conducted in Latvia and Lithuania, and 8.9\% were conducted in Italy. According to the official statistics, around 5000 labour immigrants (third-country nationals) are coming every year to Lithuania; in 2017, in Lithuania, there were around 45000 foreigners in total (EUROSTAT, 2018). Consequently, in 2017, according to EUROSTAT data, in Latvia there were 298 thousand immigrants (the biggest part of them are long-term residents); in Italy there were 3479,6 thousand immigrants; in Belgium - 434,3 thousand; in Romania - 52,5 thousand; in Bulgaria $-40,6$ thousand of immigrants. These numbers are increasing rapidly in recent years due to the asylum crisis in the European Union, and also due to the lack of labour force in Europe.

In the survey took part 1127 immigrants from 90 different countries, located outside of the EU. The vast majority (24.4\%) of immigrants were from Russia, 10.2\% from Ukraine, 8.6\% from Moldova, 3.6\% from Morocco, 3.5\% from former French colonies in Africa, 3.4\% from Belarus, from Syria - 2.9\%, from Afgha- 
nistan $-2.6 \%$, from India $-2.2 \%$, from Turkey $-1.9 \%$, Iraq $-1.8 \%$, and other countries. Gender representation was comparatively equal: $51.4 \%$ of female respondents and $48,6 \%$ of male. The youngest respondent was 16 years old at the time of the survey and the oldest -75 years old (i.e., the average age -32.11 years). For better analysis, the age groups were divided into 3 groups: 16-24 years made 34.9\%; 25-35 years $-33.9 \% ; 36$ and older $-31.2 \%$. Among the respondents $1 \%$ had no education at all, $6.4 \%$ had incomplete secondary education; $11.7 \%$ obtained secondary education; $12.8 \%$ were graduates of vocational schools and $59.9 \%$ had higher university education, and $8.2 \%$ some other education. For the analysis, five groups of immigrants according to education had been merged into two groups: (1) immigrants with no education, or secondary and secondary incomplete education, and others (31.2\%); (2) immigrants with vocational and higher education $(68.7 \%)$.

Data analysis. A variety of questions were asked in the questionnaire, but this article examines only the data that helps to answer the raised questions.

The scale 'Information that immigrants contained before their arrival in the host country' was analysed by the 16 main criteria: host country's history; people (residents) and their main traditions; the main social demographic characteristics; political system; economic system; employment legislation; ability to learn the official language; health care; education system; culture; food and culinary traditions; leisure; security; quality of service; geography, climate conditions; the main national and local holidays, and other. The scale was measured by the Likert scale (where ' 1 ' meant "I had no information", and ' 5 ' - "I had very detailed information").

Assessing the reliability of the scale 'Information that immigrants contained before their arrival in the host country' it was found that the Cronbach's alpha coefficient was 0.938 and it was considered suitable for the analysis. It was estimated that, if one variable had been removed from the scale, it would have slightly increase the coefficient of Cronbach's alpha. Considering the above-mentioned facts, it can be stated that the scale was characterized by internal coherence and was a suitable means for measurement. From the variables of this scale, the quantitative variable 'Information that immigrants contained before their arrival' has been computed and there have been investigated the links with age, gender and education. To reveal the links, the t-test and ANOVA were applied (depending on the compared number of groups).

'Information that immigrants lacked on their arrival in the host country' was analysed by the same 16 criteria. Descriptive statistics methods were used to show the major trends and representation with age, gender and education of the participants.

\section{Research results}

\subsection{Information that immigrants contained before their arrival in the host country}

The analysis of the scale's 'Information that immigrants contained before their arrival to the host country' variables have showed that the mean ranks are distributed from 6.49 to 11.01. The result of the Friedman Test indicated that there was a statistical significant difference in the information variable about the country before the arrival across the 16 positions $x^{2}=758.031(d f=15), p<0.05$. The inspection of the mean rank values showed a greater lack of information before coming to a country about geography, climate conditions (5.99), culture (7.32), the main national and local holidays (7.66), leisure (8.00), food and culinary traditions (8.08), and education system (8.42). As we can see, immigrants are mostly informed about employment legislation (10.51), a little bit less about health care (9.50) and political system (9.46), and others (Figure 1). 


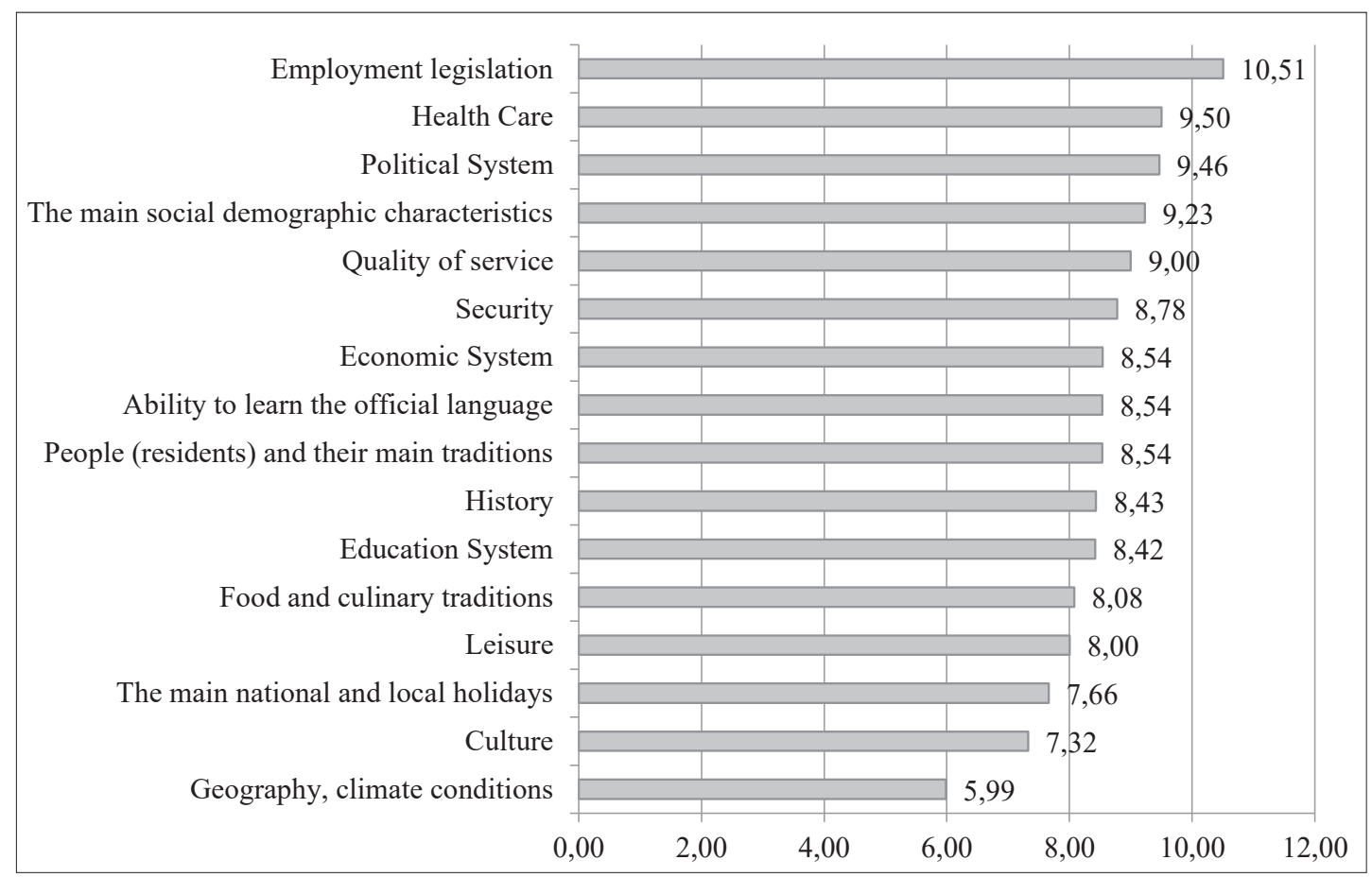

Fig. 1. Information that immigrants contained before their arrival in the host country, mean ranks

Source: research data.

The following data analysis has showed that there were statistically significant differences between the information that immigrants contained before their arrival in the host country, and education, as well as age groups. However, there were no statistically significant differences found between the information that immigrants knew before their arrival in the host country and the immigrants' gender (Table 1).

Table 1. Information that immigrants contained before their arrival in the host country and immigrants' basic sociodemographic characteristics

\begin{tabular}{|c|c|c|c|c|c|c|c|c|}
\hline \multirow{2}{*}{$\begin{array}{l}\text { Social demograph- } \\
\text { ic characteristics of } \\
\text { immigrants }\end{array}$} & \multicolumn{2}{|c|}{ Levene Statistics } & \multicolumn{3}{|c|}{ T-test or Anova } & \multirow[t]{2}{*}{ Groups } & \multirow[t]{2}{*}{ Mean } & \multirow[t]{2}{*}{ Std. } \\
\hline & $\mathbf{F}$ & $p$ & t or $F$ & df & $\mathbf{P}$ & & & \\
\hline \multirow[t]{2}{*}{ Gender } & \multirow[t]{2}{*}{2.238} & \multirow[t]{2}{*}{0.135} & \multirow[t]{2}{*}{-0.781} & \multirow[t]{2}{*}{1075} & \multirow[t]{2}{*}{0.435} & Female & 42.8109 & 21.34760 \\
\hline & & & & & & Male & 43.7926 & 19.90433 \\
\hline \multirow[t]{3}{*}{ Age } & \multirow[t]{3}{*}{14.557} & \multirow[t]{3}{*}{0.125} & \multirow[t]{3}{*}{15.699} & \multirow[t]{3}{*}{2} & \multirow[t]{3}{*}{0.000} & 16-24 years & 43.2080 & 18.94615 \\
\hline & & & & & & $25-35$ years & 47.6261 & 19.98612 \\
\hline & & & & & & $36-75$ years & 39.0144 & 22.06067 \\
\hline \multirow[t]{2}{*}{ Education } & \multirow[t]{2}{*}{2.675} & \multirow[t]{2}{*}{0.102} & \multirow[t]{2}{*}{4.237} & \multirow[t]{2}{*}{1051} & \multirow[t]{2}{*}{0.000} & $\begin{array}{l}\text { no education, secondary and } \\
\text { secondary incomplete }\end{array}$ & 47.1567 & 21.50210 \\
\hline & & & & & & $\begin{array}{l}\text { vocational and higher edu- } \\
\text { cation }\end{array}$ & 41.3542 & 19.93352 \\
\hline
\end{tabular}

Note: T-test was applied with two groups' and ANOVA with three groups' factors.

Source: research data.

Gender. The test of the homogeneity of variables shows that dispersions are homogeneous $(p>0.05)$, thus the following analysis can be performed. The inspection of the mean values showed that there are no si- 
gnificant differences between the gender groups $(t=-0.781 ; d f=1075 ; p>0.05)$. So, there is no link between gender and the information that immigrants had before their arrival in the host country.

Age. The test of the homogeneity of variables shows that dispersions are homogeneous $(p>0.05)$, therefore the following analysis can be performed. The inspection of the mean values showed that there are significant differences between the age groups $(F=15.699 ; d f=2 ; p<0.05)$. The results have showed that more information have middle aged (25-35-year-old) groups, while less information before the arrival in the host country had the older group (36-75-year-old).

Education. The test of the homogeneity of variables shows that dispersions are homogeneous $(p>0.05)$, as a result, the following analysis can be performed. The inspection of the mean values showed that there are significant differences between the education groups $(t=4.237 ; d f=1051 ; p<0.05)$. Analysis has revealed controversial results, namely that people with secondary and incomplete secondary education have more information than people with higher and vocational educational level.

\subsection{Information that immigrants lacked on their arrival in the host country}

However, analysis of the scale 'Information that immigrants lacked on their arrival in the host country' shows a different perspective. Even though immigrants knew more about employment legislation and health care, these two elements of information are still the most lacking on their arrival in the host country: health care (11.6\%); employment system (10.0\%) and ability to learn the official language $(8.8 \%)$. Yet such information as geography, climate conditions $(2.9 \%)$, the main social demographic characteristics $(3.8 \%)$ and the main national and local holidays (3.9\%) were considered less important for immigrants after their arrival in the host country (Figure 2).

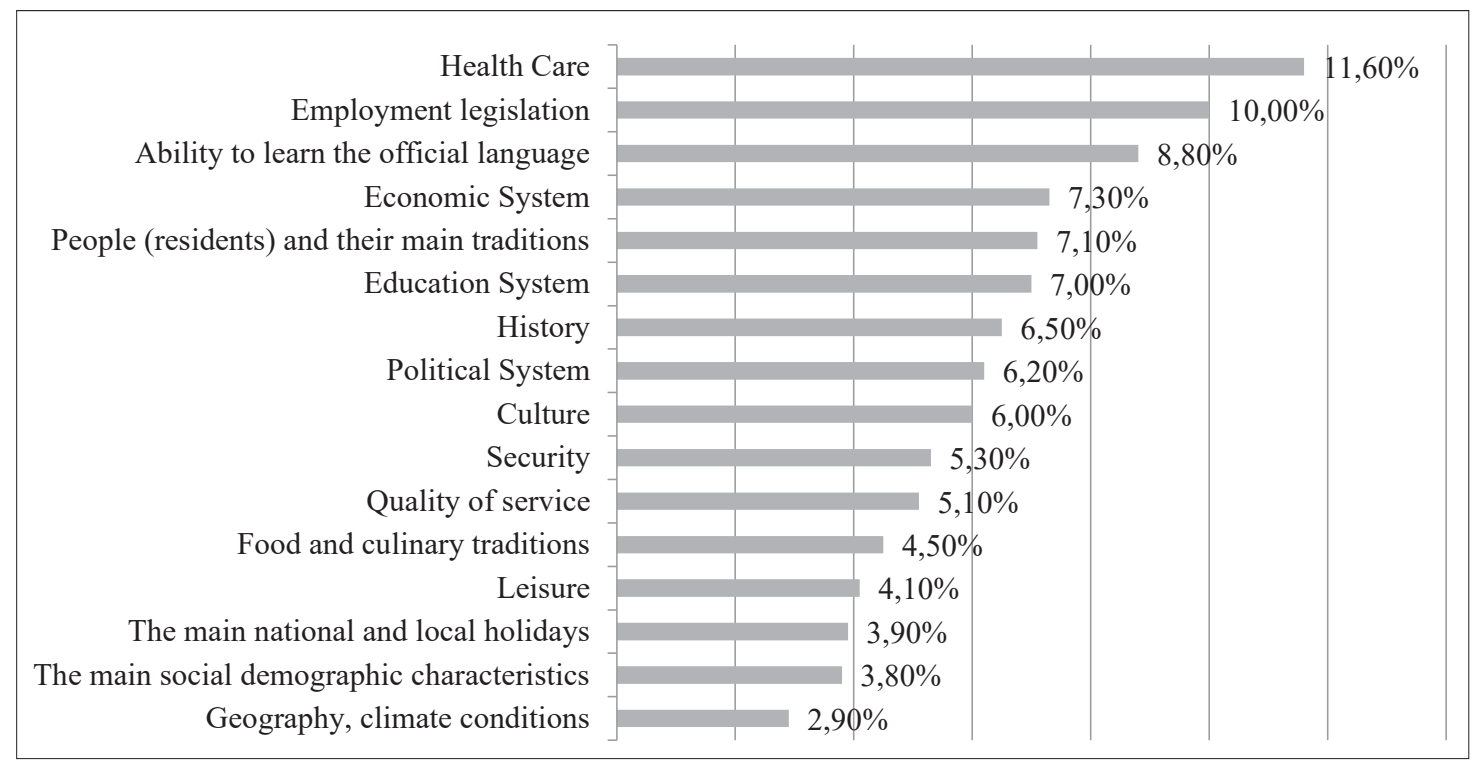

Fig. 2. Information that immigrants lacked on their arrival in the host country, $\%$

Source: research data.

Detailed analysis of this scale comparing the immigrants' basic sociodemographic characteristics has showed the following tendencies. Health care, as the most important information, immigrants lacked after their arrival in the host country, and it was much more important to middle aged (13.2\%), better educated $(12 \%)$ female respondents $(13.2 \%)$ than to male respondents. This tendency was the same with the information about employment legislation and the ability to learn official languages. 
In addition, among the most popular information that women respondents lacked was information about people (residents) and their main traditions (7.2\%), as well as economic system (7.8\%). While men respondents were more interested in security (7.8\%), education system $(7.4 \%)$ and culture $(6.5 \%)$.

Talking about the age groups, the younger group more than other age groups was interested in economic system (8.7\%), history (7.2\%), and security (5.9\%), whereas the older group lacked information about health care (14\%) and education (7.7\%). Yet the middle-aged group of the respondents lacked information on employment (12.4\%) and the ability to learn official languages (10.5\%).

Moreover, respondents belonging to the group with higher education showed greater lack of information on their arrival in the host country in all the information elements, except for educational system, which was higher for the group of respondents with lower education level (7.1\%).

Due to specific statistical data significant differences between the information, which immigrants lacked when they arrived at the host country, and sociodemographic characteristics haven't been found.

\section{Discussion and conclusions}

As it has been already mentioned in the introduction, the lack of relevant information and knowledge about the host country might cause different problems, both for immigrants and for local society. But the amount, quality and intense of information that immigrants know and receive might be unequal. Therefore, the results of the presented study confirm that information that immigrants know before their arrival to the host country, and the information that immigrants lack on their arrival to the host country is different. Thus, immigrants upon their arrival to a new country face a gap of information, i.e., between the information they have and the information they need. In other words, migrants arriving to the host country might know less about a country than they assumed to know. As A. Lloyd, M. Kennan et al. (2013) state, accessing and understanding information in the host country often require skills that can be beyond the forced migrants' proficiency of the local language, and occasionally, their literacy competency. Moreover, it is important to note, that the real need for information depends also on other different circumstances, such as family situations and learning experiences, professional practice, as well as on sociodemographic characteristics.

The results have showed that before coming to the host country immigrants knew more about employment legislation and health care, at the same time, two elements of the information which they lacked most when they arrived in the host country, were: health care; employment system and the ability to learn the official language. Similar results are also represented by N. Caidi, D. Allard and D. Dechief (2008), who reveal that the top information needs for longer established immigrants include health information, employment information, educational information, political information and current events (especially news about the country of origin), as well as language learning information.

The results demonstrate that information about health is much more important for respondents of older groups. This idea is also observed by K. Goodall, P. Ward and L. Newman (2010) in their research, where the importance of health information and use of communication technology is emphasized. Even though older migrants do not use communication technologies to a great extent for information access, they access the information by other various means, such as electronic and print media (Goodall, Ward, Newman, 2010).

Although the results have not showed any statistical differences on gender and the information that immigrants had before their arrival to the host country, in the future, this tendency should be examined more closely. Furthermore, in the scientific literature, other researches also show ambiguous information: it is important to analyse not only gender, but also the country of origin of a female migrant (Blau, Kahn, Papps, 2011). For instance, as in J. Kim's (2016) research with a Korean immigrant woman, who had common needs for information about culture learning, social roles and associated responsibilities, but less information.

At the same time, what can the results suggest on the fact that middle age immigrants with secondary and incomplete secondary education have more information than immigrants of the other age group with higher and vocational educational level? The research by N. Caidi, D. Allard and D. Dechief (2008) also proves it observing students who struggled with lack of information. 
The future research should include analysis on the needs for information and immigration destinations countries, as well as information sources and how they are related to sociodemographic characteristics. Also, a sociolinguistic perspective as an important factor in information practices should not be eliminated.

\section{References}

Action Plan on the Integration of Third Country Nationals (2016). Communication from the Commission to the European Parliament, the Council, the European Economic and Social Committee and the Committee of the Regions. Brussels. Available at: https://ec.europa.eu/home-affairs/sites/homeaffairs/files/what-we-do/policies/ european-agenda-migration/proposal-implementation-package/docs/20160607/communication_action_plan_integration_third-country_nationals_en.pdf

Algan, Y., Dustmann, C., Glitz, A., Manning, A. (2010). The Economic Situation of First and Second-Generation Immigrants in France, Germany and the United Kingdom. The Economic Journal, Vol. 120(542).

Andrade, A. D., Doolin, B. (2016). Information and Communication Technology and the Social Inclusion of Refugees. Mis Quarterly, Vol. 40(2), p. 405-416.

BBC News. (2016). Migrant Crisis: Migration to Europe Explained in Seven Charts. Available at: http://www.bbc.com/ news/world-europe-34131911

Blau, F. D., Kahn, L. M., Papps, K. L. (2011). Gender, Source Country Characteristics, and Labor Market Assimilation among Immigrants. The Review of Economics and Statistics, Vol. 93(1), p. 43-58.

Caidi, N., Allard, D. (2005). Social Inclusion of Newcomers to Canada: An Information Problem? Library Information Science Research, Vol. 27(3), p. 302-324.

Caidi, N., Allard, D., Dechief, D. (2008). Information Practices of Immigrants to Canada: A Review of the Literature. Unpublished Report to Citizenship and Immigration Canada. March 31, 2008. Available at: https://www.academia. edu/1288629/Information_Practices_of_Immigrants_to_Canada_A_Review_of_the_Literature

Castells, M. (2009). Communication Power. Oxford, New York: Oxford University Press. 571 p.

Dekker, B., Siegel, M. (2013). Transnationalism and Integration: Complements or Substitutes? Research output. Available at: https://cris.maastrichtuniversity.nl/portal/en/publications/transnationalism-and-integration--complementsor-substitutes(df4bbaea-1c75-4329-a102-62c153295917).html

Determining Labour Shortages and the Need for Labour Migration from Third Countries in the EU. (2015). International Migration Organisation. Available at: http://emn.lt/wp-content/uploads/2015/05/emn_focussed_study_determining_labour_migration_shortages.pdf

EUROSTAT. (2018). Available at: http://ec.europa.eu/eurostat

Goodall, K., Ward, P., Newman, L. (2010). Use of Information and Communication Technology to Provide Health Information: What Do Older Migrants Know, and What Do They Need to Know? Quality in Primary Care, Vol. 18(1).

Kim, J. (2016). Information practices during life transition: Korean immigrant women's everyday life information seeking and acculturation. Doctoral dissertation. University of Maryland, College Park.

Lloyd, A., Kennan, M., Thompson, K. M., Qayyum, A. (2013). Connecting with New Information Landscapes: Information Literacy Practices of Refugees. Journal of Documentation, Vol. 69(1), p. 121-144.

Mehra, B., Papajohn, D. (2007). "Glocal” Patterns of Communication-Information Convergences in Internet Use: Cross Cultural Behaviour of International Teaching Assistants in a Culturally Alien Information Environment. International Information Library Review, Vol. 39, p. 12-30.

Population Reference Bureau. (2018). Available at: http://www.prb.org/

Rechel, B., Mladovsky, P., Ingleby, D., Mackenbach, J. P., McKee, M. (2013). Migration and Health in an Increasingly Diverse Europe. The Lancet, Vol. 381(9873), p. 1235-1245.

Redecker, C., Haché, A., Centeno, C. (2010). Using Information and Communication Technologies to Promote Education and Employment Opportunities for Immigrants and Ethnic Minorities. Joint Research Centre, European Commission.

Shoham, S., Strauss, S. K. (2008). Immigrants' Information Needs: Their Role in the Absorption Process. Information Research, Vol. 13(4).

World Bank. (2018). Available at: http://www.worldbank.org/ 


\title{
INFORMACIJA APIE ŠALI PRIEŠ IMIGRUOJANT I JĄ: KAIP JI SUSIJUSI SU PAGRINDINEMIS IMIGRANT U SOCIODEMOGRAFINEMIS CHARAKTERISTIKOMIS
}

\author{
Aleksandra Batuchina, Regina Saveljeva, Gunta Viksne, Zornitca Staneva
}

\section{Santrauka}

Šiandien migracija - didelis iššūkis tiek patiems imigrantams, tiek ir juos priimančioms šalims. $2011 \mathrm{~m}$. Europos Komisija nustate poziciją dèl trečiųjų šalių piliečiu integracijos į Europą, kuri Europos Sajungai būtų naudinga ekonominiu, socialiniu ir kultūriniu požiūriu. Siekta, kad imigrantų integracija Europos Sąjungoje būtų sẻkminga, o nauji visaverčiai bendruomenès nariai aktyviai dalyvautų priimančių miestų ir regionų ekonominiame, socialiniame, kultūriniame ir politiniame gyvenime (Action Plan on the integration of third country nationals, 2016). Verta pastebèti, kad kuo sèkmingesnè bus imigrantų integracija, tuo didesnis bus jų ekonominis ir fiskalinis indèlis ị priimančiąją ekonomiką (Algan, Dustmann, Glitz, Manning, 2010).

Vienas sėkmingos integracijos veiksnių - informacija apie priimančiają šalį. Tyrimai atskleidè, kad neseniai i priimančiąją šalị atvykę imigrantai dažnai moka šalies kalbą, bet nepažịsta jos gyvenimo vertybių, normų ir tradicijų, socialinio gyvenimo ir kultūrinių ypatybių (Algas, Dustmanas, Glitsas, Maningas, 2010). Taigi neinformuoti asmenys rizikuoja būti išstumti iš pagrindinių informacijos šaltinių ir gali nepajègti visapusiškai pažinti šalies, žmonių, pasinaudoti galimybėmis, dalyvauti visuomenės gyvenime kaip tos šalies piliečiai.

Nepaisant informacijos šaltinių, net jos kiekio ir kliūčių, kurių gali kilti, nesant tokios informacijos, visada yra iššūkių, dẻl kurių sumažèja arba padidejja prieiga prie informacijos: kalba, kultūriniai skirtumai, izoliacija ir siauri bendravimo tinklai, prieiga prie vietos naujienų ir kitų šaltinių (Caidi, Allard, Dechief, 2008). Be to, kaip teigia N. Caidi, D. Allard, D. Dechief (2008), priimant informaciją svarbios ir demografinès charakteristikos: amžius, lytis, išsilavinimas. Nors akivaizdu, kad šie demografiniai veiksniai gali lemti sèkmingą ir orią migrantų integraciją priimančiojoje šalyje, jie gali skatinti ir socialinę atskirtị, žmonių atsiskyrimą, kitas socialines bẻdas bei aspektus. Šios trys demografinès charakteristikos ir jų sąsajos mokslinèje literatūroje mažai nagrinètos, todèl šio straipsnio tikslas - nustatyti, kaip informacija apie priimančiają šali susijusi su pagrindinėmis imigrantų sociodemografinėmis charakteristikomis: amžiumi, lytimi ir išsilavinimu. Duomenų rinkimo metodas - anketinè apklausa. Duomenų analizės metodai: neparametrinè ir aprašomoji statistinè analizè.

Straipsnyje pristatomi ir analizuojami duomenys iš tyrimo, kuris atliktas $2017 \mathrm{~m}$. Lietuvoje, Latvijoje, Rumunijoje, Bulgarijoje, Italijoje ir Belgijoje. Tyrimas atliktas vykdant Erasmus + projektą „Suaugusiujų imigrantų pirminio švietimo tobulinimas“ (Nr. 2016-1-LT01-KA204-023223). Tyrime dalyvavo 1127 imigrantai iš 90 ne ES valstybių.

Duomenų analizė atskleidè, kad ryšys tarp migrantų turètos informacijos prieš atvykstant ị priimančiają šalị ir išsilavinimo bei amžiaus grupių yra. Tuo tarpu ryšys tarp lyties ir tokios informacijos turejjimo nenustatytas. Imigrantams jau atvykus ị naują šalị labiausiai reikejjo informacijos dèl sveikatos apsaugos, ịsidarbinimo ir kalbos kursų.

Būsimi tyrimai turètų apimti informacijos poreikio, šaltinių ir kitų socialinių-demografinių charakteristikų analizę. Be to, neturètų būti atmetama ir sociolingvistinè perspektyva, kaip svarbus informacijos praktikos veiksnys.

PAGRINDINIAI ŽODŽIAI: migracija, informacinè praktika, socialinès-demografinès charakteristikos. 